\title{
Spatial and temporal variability in summer snow pack in Dronning Maud Land, Antarctica
}

\author{
T. Vihma ${ }^{1}$, O.-P. Mattila ${ }^{2, *}$, R. Pirazzini ${ }^{1}$, and M. M. Johansson ${ }^{1}$ \\ ${ }^{1}$ Finnish Meteorological Institute, P.O. Box 503, 00101 Helsinki, Finland \\ ${ }^{2}$ Department of Physics, University of Helsinki, P.O. Box 64, 00014 Helsinki, Finland \\ * now at: Finnish Environmental Institute, P.O. Box 140, 00251 Helsinki, Finland
}

Received: 30 June 2010 - Published in The Cryosphere Discuss.: 22 July 2010

Revised: 3 February 2011 - Accepted: 23 February 2011 - Published: 10 March 2011

\begin{abstract}
To quantify the spatial and temporal variability in the snow pack, field measurements were carried out during four summers in Dronning Maud Land, Antarctica. Data from a $310-\mathrm{km}$-long transect revealed the largest horizontal gradients in snow density, temperature, and hardness in the escarpment region. On the local scale, day-to-day temporal variability dominated the standard deviation of snow temperature, while the diurnal cycle was of second significance, and horizontal variability on the scale of 0.4 to $10 \mathrm{~m}$ was least important. In the uppermost $0.2 \mathrm{~m}$, the snow temperature was correlated with the air temperature over the previous $6-12 \mathrm{~h}$, whereas at the depths of 0.3 to $0.5 \mathrm{~m}$ the most important time scale was 3 days. Cloud cover and radiative fluxes affected the snow temperature in the uppermost $0.30 \mathrm{~m}$ and the snow density in the uppermost $0.10 \mathrm{~m}$. Both on the intra-pit and transect scales, the ratio of horizontal to temporal variability increased with depth. The horizontal standard deviation of snow density increased rapidly between the scales of 0.4 and $2 \mathrm{~m}$, and more gradually from 10 to $100 \mathrm{~m}$. Inter-annual variations in snow temperature and density were due to interannual differences in air temperature and the timing of the precipitation events.
\end{abstract}

\section{Introduction}

Horizontal heterogeneity in the snow pack is primarily introduced by the underlying topography, which influences the distribution of accumulation, and by the prevailing meteorological conditions, through mechanical stress by wind and melting due to radiation and air-snow heat flux (Colbeck, 1991; Rotschky et al., 2007). Even slight

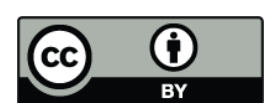

Correspondence to: T. Vihma

(timo.vihma@fmi.fi) topographic variations interacting with the weather often generate horizontal heterogeneity (Frezzotti et al., 2002a, b). Synoptic-scale variations in weather generate heterogeneity in the snow pack at scales of tens to hundreds of kilometres but, according to Sturm and Benson (2004), the heterogeneity often approaches a peak value at a scale of $100 \mathrm{~m}$, related to wind-drift structures of approximately this size. The layering of the snow pack is developed by metamorphic processes driven by the flow of water vapor and melt water transporting heat and mass, as well as by densification through volumetric creep (Harper and Bradford, 2003; Li and Zwally, 2004). The layering affects the thermal conductivity and may direct and block the flow of water vapor and melt water (Colbeck, 1991). Layers formed during windy conditions are likely to be more spatially variable than other layers (Kronholm et al., 2004).

Temporal variability in the snow properties is related to diurnal, synoptic-scale and seasonal changes in weather, above all the solar radiation, air temperature, precipitation, and wind speed. On the annual scale, snow density and hardness increase in summer due to thermally-driven metamorphosis and melt (Li and Zwally, 2004). The temporal variability of snow temperature decreases with depth. In winter the depthdependence of temperature is dominated by heat conduction, but in summer solar radiation and water vapour transport are also important (Brandt and Warren, 1997; Town et al., 2008).

In the Antarctic the snow pack is to a large extent wind packed with a small grain size. In the coastal zone, horizontal gradients in wind speed, precipitation, air temperature, and air humidity are large (King and Turner, 1997). Summer melt affects the snow pack properties in the coastal zone, while melt remains unimportant for the mass balance of the whole ice sheet. Snow measurements in the Antarctic are very sparse but quantitative information on the snow pack properties are needed for numerous reasons.

Published by Copernicus Publications on behalf of the European Geosciences Union. 
Information on snow density is required to convert satellite observations of changes in the ice sheet elevation to mass changes (McConnell et al., 2000; Zwally and Li, 2002) and to estimate the water equivalent surface mass balance on the basis of stake measurements (Takahashi and Kameda, 2007). Anomalies in snow temperature and accumulation are positively correlated but have an opposing effect on the firn layer thickness (Helsen et al., 2008). This is because major snow fall events occur at high air temperatures, the snow fall increases the firn layer thickness but the high air temperatures enhance densification of the upper snow layers. From the point of view of the change in glacier elevation, the variations in accumulation are, however, far more important than the changes in temperature (Helsen et al., 2008).

Conclusions on the representativeness of point measurements require knowledge on spatial variability. This is particularly important for the interpretation of accumulation measurements (Wingham, 2000; Frezzotti et al., 2004; Rotschky et al., 2007) and other ice core results (Reijmer et al., 2002). Data on the spatial and temporal variability in the snow pack are essential for validating glaciological models (Dadic et al., 2008) and for use as lower boundary conditions for climate and numerical weather prediction models (Tastula and Vihma, 2011). Temporal variability in snow thickness, density, temperature, and stratigraphy is important for studies of snow surface energy and mass balance (Nicolaus et al., 2009). The diurnal cycle of snow temperature and metamorphosis strongly affects the surface albedo (Pirazzini, 2004) and air-snow exchange of chemical components (Frey et al., 2009).

The above calls for more observations on spatial and temporal variability in the snow pack. To respond to this need, we have carried out snow measurements in the coastal zone of Dronning Maud Land during four austral summers, as a part of the Finnish Antarctic Research Programme (FINNARP). We analyse the spatial variability of snow temperature, density and layering on five different scales: < $1 \mathrm{~m}, 10-20 \mathrm{~m}, 100 \mathrm{~m}, 50 \mathrm{~km}$, and 100-300 km. We analyse the temporal variability on the diurnal, synoptic, and inter-annual scales, with additional focus on the effects of clouds and radiative fluxes. Our study has the following objectives:

1. to quantify the spatial and temporal variability in snow temperature, density and layering in a coastal region with large gradients in weather conditions,

2. to better understand the relative importance of the spatial and temporal variability, and

3. to better understand the representativeness of point measurements, also obtaining a better basis for planning future field campaigns.

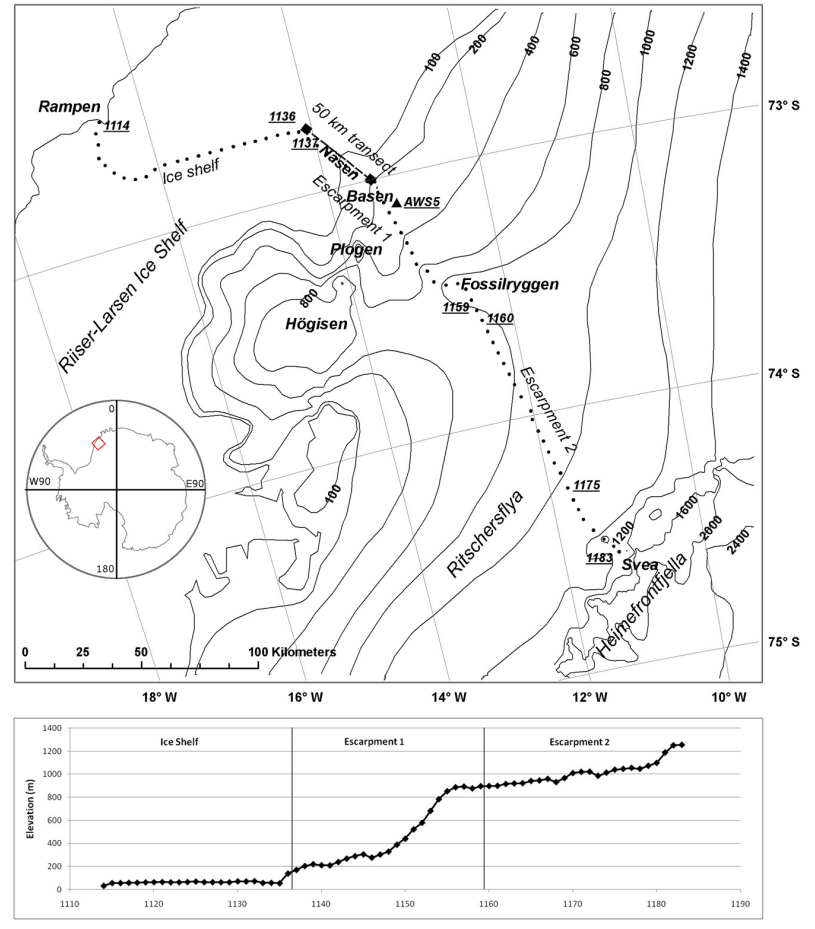

Fig. 1. Map of the research area and profile of elevation for the 310$\mathrm{km}$-long transect. Each measurement site along the transect is identified by the code 11 followed by a progressive mass balance stake number, from 14 at the coast to 83 at the innermost site (sites 1114 , $1136,1137,1159,1160$, and 1183 are marked in the map). The region marked as Ice shelf extends from 1114 to 1136, the Escarpment 1 from 1137 to 1159 , and Escarpment 2 from 1160 to 1183. The crosses mark the locations of the Basen and Svea Stations.

\section{Study area and its climate}

The study area covers a coastal region of Dronning Maud Land with Riiser-Larsen ice shelf in the west (Fig. 1). At the grounding line the ice shelf has a long peninsula called Näsen. From the grounding line the ice sheet rises gently towards the first two nunataks of the Vestfjella mountain range, Basen and Plogen. The Finnish research station, Aboa, is situated on the Basen nunatak. In summer, parts of the nunatak become snow-free and are strongly heated by solar radiation, but the effects are not felt at our snow measurement site $2 \mathrm{~km}$ from the nunatak. South-west of Basen and Plogen is the large ice rise of Högisen, with an altitude of $900 \mathrm{~m}$ a.s.1. The ice sheet rises gently towards the southeast until it reaches a small separate rock outcrop, Fossilryggen, where the slope of the ice sheet becomes steeper. South of Fossilryggen, the Ritchersflya ice sheet opens out, which is bounded to the south by the Heimefrontfjella mountain range that restrains the ice mass of the main Antarctic ice sheet.

The climate of the study region varies with the distance from the coast. The effect of transient cyclones that travel eastward along the coast decreases inland, whereas the effect 
of katabatic winds is strongest over the steepest slopes. On the basis of previous observations (Van den Broeke et al., 1999, 2004; Reijmer and Oerlemans, 2002; Reijmer and Van den Broeke, 2003; Granberg et al., 2009), our study region can be divided into two climatic zones: the ice shelf and the sloping escarpment region (consisting of Escarpment 1 between Basen and Fossilryggen, and Escarpment 2 between Fossilryggen and Svea; Fig. 1). The surface radiation budget over the whole study area is negative for most of the year and slightly positive during summer (Van den Broeke et al., 2004). During winter, the surface radiative loss is larger over the sloping surfaces of the escarpment region than on the flat ice shelf (Van den Broeke et al., 2004). The winter radiative loss is mostly compensated for by the sensible heat flux from the air to the surface (Reijmer and Oerlemans, 2002). Due to the strength of the wintertime katabatic flow over the sloping areas, the annual mean wind speed is about $1.5 \mathrm{~m} \mathrm{~s}^{-1}$ stronger in the escarpment region near Basen and at Svea station than over the coastal ice shelf (Reijmer and Oerlemans, 2002).

Rotschky et al. (2007) combined data from field campaigns in the western Dronning Maud Land over a 15-yr period, and provided detailed information on the spatial distribution of snow accumulation, quantifying its decrease from the coastal areas to the high plateau. The general spatial distribution in accumulation over the area maintains a rather typical pattern from year to year, but there are substantial variations in absolute accumulation between years (Richardson at al., 1997; Reijmer and van den Broeke, 2003; Richardson-Näslund, 2004). The snow properties are affected by the local topography and distance from the moisture source at the coast (Kärkäs et al., 2002, 2005).

\section{Observations and methods}

In summers 2003-2004 and 2004-2005 we made snow observations along a $310-\mathrm{km}$-long transect, and in summers 2006-2007 and 2007-2008 close to Basen nunatak (Fig. 1). The observations are summarized in Table 1.

\subsection{Methods}

Two different methods were used to determine the snow density. The 310-km-long transect was sampled using a snow fork (Sihvola and Tiuri, 1986). In the snow pits close to Basen nunatak, the vertical snow density profiles were measured with a steel cylinder, pushed horizontally in the snow pit wall. In 2006-2008 the density at the uppermost $0.02 \mathrm{~m}$ was measured using a small aluminium box (Table 1). To provide information on the accuracy of the snow fork, we show in Fig. 2 a comparison of snow densities based on the cylinder and snow fork measurements in six 1-m-deep snow pits during previous field work carried out in summer 20002001 in the same area using the same equipment (Kärkäs et

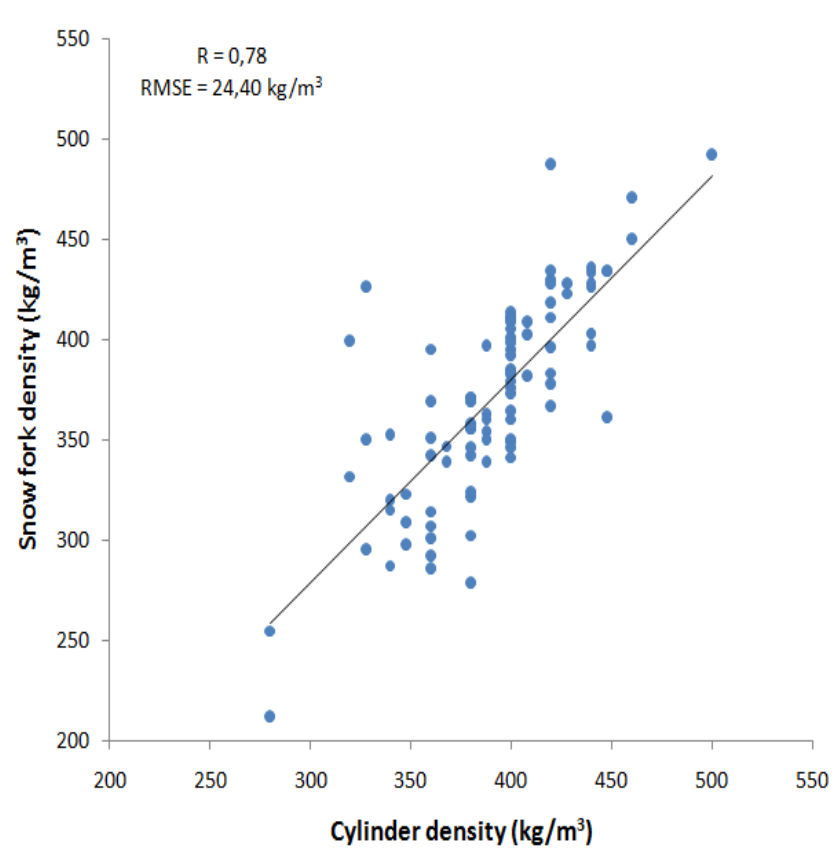

Fig. 2. Comparison of snow density measured using the cylinder and snow fork. The data include 93 simultaneous measurement pairs from the same depth in the uppermost $0.5 \mathrm{~m}$ layer.

al. 2002). Considering the cylinder measurements to represent the truth, the root-mean-square error for the snow fork was $24 \mathrm{~kg} \mathrm{~m}^{-3}$. The correlation coefficient $(r)$ between the two data sets was 0.78 .

The snow temperature was measured with three types of handheld temperature probes, all having an accuracy of $\pm 0.2^{\circ} \mathrm{C}$ : Testo 4110 , with a $0.30 \mathrm{~m}$ probe, Ebro TFX 392 , with a $0.15 \mathrm{~m}$ probe and Ebro TLC1598, with a $0.15 \mathrm{~m}$ probe. The traditional subjective hardness test for snow (Colbeck et al., 1990) was used to make observations of the vertical structure of layering in the snow. Layering was determined with $0.01 \mathrm{~m}$ resolution. The classes of the hand test are coded as shown in Table 2.

\subsection{Measurements near Basen nunatak in summers 2006-2007 and 2007-2008}

During the snow measurements near Basen nunatak (Table 1), a new snow pit was excavated for each set of vertical temperature and density profiles. The following measurements were made in both summers once or twice a day:

a. Snow temperature profiles in the snow pits. The temperature was measured by inserting the probe horizontally into the snow at depths of $0,0.025,0.05,0.10$, $0.15,0.20,0.25,0.30,0.40$, and $0.50 \mathrm{~m}$. The probe was also pushed downward from the bottom of the snow pit, to reach a depth of $0.90 \mathrm{~m}$. In each snow pit one to three (on average 2.3 ) vertical profiles with approximately $0.4 \mathrm{~m}$ horizontal intervals were measured. It 
Table 1. Snow measurements. Snow temperature is denoted by $T$, snow density by $\rho$, and subjective layer hardness by $H$.

\begin{tabular}{|c|c|c|c|c|c|c|c|}
\hline Period & Site & Variables & Depth & Horizontal resolution & Number of snow pits & Equipment & Accuracy (rms error) \\
\hline 3 December 2003 & $10 \mathrm{~km}$ south of Basen & $\rho$ & $0.5 \mathrm{~m}$ & $25 \mathrm{~m}$ & 8 & Snow fork & $24 \mathrm{~kg} \mathrm{~m}^{-3}$ for $\rho$ \\
\hline $\begin{array}{l}13 \text { December } 2003 \text { to } \\
15 \text { January } 2004\end{array}$ & $310 \mathrm{~km}$ transect & $\rho \mathrm{H}$ & $0.5 \mathrm{~m}$ & $5 \mathrm{~km}$ & $\begin{array}{l}63 \text {, for } \rho \\
70, \text { for } H\end{array}$ & Snow fork & $24 \mathrm{~kg} \mathrm{~m}^{-3}$ for $\rho$ \\
\hline $\begin{array}{l}20 \text { December } 2004 \text { to } \\
11 \text { January } 2005\end{array}$ & $310 \mathrm{~km}$ transect & $\rho H T$ & $0.5 \mathrm{~m}$ & $5 \mathrm{~km}$ & 70 & $\begin{array}{l}\text { Snow fork }{ }^{2} \text { Ebro TFX } 392 \\
\text { and Ebro TLC } 1598 \text { thermo- } \\
\text { meters with } 0.15 \text { m probes }\end{array}$ & $\begin{array}{l}24 \mathrm{~kg} \mathrm{~m}^{-3} \text { for } \rho \\
\pm 0.2^{\circ} \mathrm{C} \text { for } T\end{array}$ \\
\hline 5 to 29 January 2007 & near Basen & $\rho T$ & $\begin{array}{l}0.5 \mathrm{~m} \text { for } \rho \\
0.9 \mathrm{~m} \text { for } T\end{array}$ & $\begin{array}{l}0.4 \mathrm{~m} \\
0.4 \mathrm{~m}\end{array}$ & $\begin{array}{l}45 \text { for } T \\
37 \text { for } \rho\end{array}$ & $\begin{array}{l}\text { Testo } 4110 \text { thermometer } \\
\text { with a } 0.30 \mathrm{~m} \text { probe Density } \\
\text { cylinder }^{1} \text { and box }{ }^{3}\end{array}$ & $\begin{array}{l}8 \mathrm{~kg} \mathrm{~m}^{-3} \text { for } \rho \\
8 \mathrm{~kg} \mathrm{~m}^{-3} \text { for } \rho\end{array}$ \\
\hline $\begin{array}{l}23 \text { December } 2007 \text { to } \\
28 \text { January } 2008\end{array}$ & near Basen & $\rho T$ & $\begin{array}{l}0.5 \mathrm{~m} \text { for } \rho, \\
90 \mathrm{~cm} \text { for } T\end{array}$ & $\begin{array}{c}0.4 \mathrm{~m} \text { in snow pits, } \\
1 \mathrm{~m} \text { in horizontal } \\
\text { profiles }\end{array}$ & $\begin{array}{l}32 \text { for } T, 27 \text { for } \rho \text {, } \\
13 \text { horizontal profiles } \\
\text { for } T, 7 \text { for } \rho\end{array}$ & $\begin{array}{l}\text { Testo } 4110 \text { thermometer } \\
\text { with a } 0.30 \mathrm{~m} \text { probe Density } \\
\text { cylinder }^{1} \text { and box }{ }^{3}\end{array}$ & $\begin{array}{l} \pm 0.2^{\circ} \mathrm{C} \text { for } T \\
8 \mathrm{~kg} \mathrm{~m}^{-3} \text { for } \rho^{4}\end{array}$ \\
\hline
\end{tabular}

${ }^{1}$ diameter $0.05 \mathrm{~m}$, length $0.13 \mathrm{~m},{ }^{2}$ width $0.01 \mathrm{~m}$, length $0.06 \mathrm{~m},{ }^{3}$ height $0.02 \mathrm{~m}$, length $0.06 \mathrm{~m}$, width $0.04 \mathrm{~m},{ }^{4}$ snow mass in cylinder measured with an accuracy of $0.002 \mathrm{~kg}$.

Table 2. Nomination of classes of subjective hardness, adopted from Colbeck et al. (1990).

\begin{tabular}{lll}
\hline Class name & Hand test & Hardness \\
\hline 1 & Fist & Very low \\
2 & 4 fingers & Low \\
3 & 1 finger & Medium \\
4 & Pencil & High \\
5 & Knife & Very high \\
6 & - & Ice \\
\hline
\end{tabular}

was difficult to push the 0.30 -m-long probe exactly horizontally into the snow pack, and the accuracy of the measurement depth was studied in the field. In January 2007 , a systematic error of $0.02-0.06 \mathrm{~m}$, increasing with depth, was detected, and a correction was applied to the depth data. In December 2007-January 2008, no systematic error was found.

b. Snow density measurements in the snow pits. The density was measured at depths of $0.01,0.10,0.20,0.30$, 0.40 , and $0.50 \mathrm{~m}$. The samples were not melted but weighted directly. In each snow pit one or two vertical density profiles, with a horizontal interval of approximately $0.4 \mathrm{~m}$, were measured.

Horizontal variability was studied in summer 20072008 by making the following measurements with $1-\mathrm{m}$ intervals along lines 10-20 $\mathrm{m}$ long.

c. Horizontal profiles of snow temperature. The temperature was measured by pushing the probe vertically to depths of $0.025,0.10$, and $0.20 \mathrm{~m}$.

d. Horizontal profiles of snow density. The samples were taken from the depths of $0.05,0.10$, and $0.20 \mathrm{~m}$.
We made meteorological measurements at the snow pit site during both summers. The air temperature and wind speed were measured at five heights, between 0.4 and $6.5 \mathrm{~m}$, by instruments mounted on a mast. The upward and downward components of solar shortwave radiation were measured using two Eppley PSP pyranometers, whereas two Eppley PIR pyrgeometers were used to measure upward and downward thermal longwave radiation. The radiation sensors were checked once or twice a day for horizontal levelling and ice/snow accretion. Visual observations of cloud fraction and type and occurrences of snow fall were made in both summers once an hour usually from 08:00 to 22:00 UTC.

\subsection{Large-scale measurements in summers 2003-2004 and 2004-2005}

Along the $310 \mathrm{~km}$ transect, snow density was measured with the snow fork every $0.02 \mathrm{~m}$ from the surface down to $0.50 \mathrm{~m}$, and the layering was identified with $0.01 \mathrm{~m}$ vertical resolution. The horizontal distance between the pits was $5 \mathrm{~km}$. The snow temperature was only measured in 2004-2005 at the following depths: $0,0.025,0.05,0.075,0.10,0.15,0.20$, $0.25,0.30,0.35,0.40,0.45$ and $0.50 \mathrm{~m}$. Further, a $50 \mathrm{~km}$ subsection of the entire transect, covering the subglacial peninsula Näsen and part of the ice shelf (Fig. 1), was measured four times in a two week interval during 2004-2005. In addition, in summer 2003-2004, snow density (using the cylinder) and layering in the top $0.50 \mathrm{~m}$ were measured $10 \mathrm{~km}$ south of Basen. In a $100 \mathrm{~m} \times 75 \mathrm{~m}$ area, eight pits separated by $25 \mathrm{~m}$ were examined.

\subsection{Meteorological model products}

We utilized the operational analyses from the European Centre for Medium-Range Weather Forecasts (ECMWF). The analyses are based on a global forecast model at T799 resolution (approximately $25 \mathrm{~km}$ in the horizontal). The temporal resolution is $6 \mathrm{~h}$. Snow fall, 2-m air temperature, and $10-\mathrm{m}$ 
wind speed were collected from the ECMWF data archive. The 2-m air temperature and 10-m wind speed are analyses based on 6-h forecasts (as the first-guess field) and assimilated observations. No precipitation observations were, however, assimilated in the model. To avoid errors due to the model spin-up period (Tietäväinen and Vihma, 2008), we have made use of the 24-h precipitation forecasts. ECMWF has produced the most accurate reanalysis for the Southern Hemisphere (Bromwich and Fogt, 2004; Monaghan et al., 2006; Bromwich et al., 2007; Dell'Aquila et al., 2007). Considering inter-annual variations, Monaghan et al. (2006) showed that precipitation trends in the ERA-40 reanalysis of the ECMWF were in good agreement with ice core data. Further, compared to ERA-40, the operational analyses applied in this study benefit from a newer model version, a better data-assimilation scheme, as well as improved horizontal and vertical resolution.

We made additional validation of the ECMWF model products. First, we compared the ECMWF-based snow fall against the observed accumulation climatology in the Dronning Maud Land as presented in Rotschky et al. (2007). The annual mean snow accumulation in the period 19892008 was $0.33 \mathrm{~m}$ water equivalent per year (w.e. $\mathrm{yr}^{-1}$ ) at

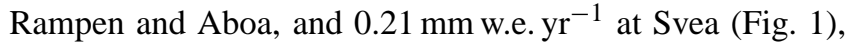
which agrees well with the results of Rotschky et al. (2007) (see their Fig. 5). We also validated the ECMWF operational analyses for 2-m air temperature and 10-m wind speed against our observations from close to Basen taken during summers 2006-2007 and 2007-2008. The ECMWF 2-m air temperature had a good correlation with the observations $(r=0.79)$, a bias of $-0.8^{\circ} \mathrm{C}$, and a root-mean-square error (rmse) of $2.1^{\circ} \mathrm{C}$. The corresponding numbers for the $10-\mathrm{m}$ wind speed were $0.72(r),-1.0 \mathrm{~m} \mathrm{~s}^{-1}$ (bias), and $2.1 \mathrm{~m} \mathrm{~s}^{-1}$ (rmse). Considering inter-annual differences, on the basis of our observations January was $2.6^{\circ} \mathrm{C}$ warmer in 2007 than 2008, and according to ECMWF the difference was $2.3^{\circ} \mathrm{C}$. The observed wind speed was $1.0 \mathrm{~m} \mathrm{~s}^{-1}$ stronger in January 2007, whereas the ECMWF yielded a difference of $0.5 \mathrm{~m} \mathrm{~s}^{-1}$. Bearing in mind the numerous problems that meteorological models have in the Antarctic (Vihma et al., 2002; Tastula and Vihma, 2011), the results were very encouraging.

\section{Data analyses and results}

\subsection{Spatial and temporal variability close to Basen}

The mean temperature and density profiles were calculated for each snow pit and for each day. Then the mean profiles for the whole summers 2006-2007 and 2007-2008 were calculated. Standard deviations of temperature and density were calculated for each measurement depth to detect (a) intra-pit spatial variability on the horizontal scale of approximately $0.4 \mathrm{~m}$, based on almost simultaneous measurements (only 15 min time interval), (b) diurnal cycle, based on temporal standard deviation of pit-averaged data collected within a day, (c) day-to-day variability, based on temporal standard deviation of diurnal means observed during the summer, and (d) total variability of all observations. Vertical profiles of these standard deviations were then analysed.

The measurement conditions were classified as either clear or cloudy according to the following rules: clear, if the observed total cloud fraction was $0-3 / 8$, and cloudy, if the total cloud fraction was 6-8/8. In the "clear" conditions, the clouds were usually high or medium clouds, while in cloudy conditions the clouds were usually low or medium clouds. The profiles were further classified into morning profiles (measurements before 11:00 UTC, 10 solar time) and evening profiles (18:00-22:00 UTC, 17-21 solar time). (Because of other field work, very few snow measurements were made between 11:00 and 18:00 UTC.) In the summer of 2007-2008, by chance, no evening profiles were measured during cloudy days.

\subsubsection{Snow temperature}

The variability of snow temperature was dominated by the day-to-day temporal variability (standard deviation (std) exceeded $2{ }^{\circ} \mathrm{C}$ in the uppermost centimetres). The diurnal cycle was of next significance (std exceeded $1{ }^{\circ} \mathrm{C}$ ) and the intrapit spatial variability was the smallest component (std less than $0.5^{\circ} \mathrm{C}$ at all depths) (Fig. 3). The total and day-to-day small-scale variability was largest at the snow surface, decreasing exponentially with an e-folding depth $(h)$ of 0.25 to $0.30 \mathrm{~m}: \operatorname{std}_{z}=\operatorname{std}_{0} \mathrm{e}^{-z / h}$, where $\operatorname{std}_{z}$ is the standard deviation of temperature at depth $z$ and $\operatorname{std}_{0}$ is that at the snow surface. As new snow pits were made at locations typically $1-10 \mathrm{~m}$ from the previous ones, the day-to-day temporal variability and diurnal cycle results also included a contribution from spatial variability. The temporal variability on the day-today scale was, however, much larger than the diurnal cycle. This demonstrates that the contribution from spatial variability (practically same for the day-to-day variability and diurnal cycle) must have been minor. This is supported by the results from the horizontal profile measurements (see below).

In summer 2007-2008 the snow temperatures were as much as $1.4^{\circ} \mathrm{C}$ lower than in the previous summer (Fig. 3). This was due to lower air temperatures: we observed that January was $2.6^{\circ} \mathrm{C}$ colder in 2008 than in 2007 . According to ECMWF analyses, however, the two months preceeding the observations were $0.6^{\circ} \mathrm{C}$ warmer in 2007 than in 2006 and the six preceeding months in 2007 were $1.9^{\circ} \mathrm{C}$ warmer than those in 2006. The uppermost $50 \mathrm{~cm}$ of the snow pack reacts so rapidly to the atmospheric forcing, in particular during summer when solar radiation is strong, that the mean temperature during the month of observations was more important than that during the preceding months. At the depth of $0.90 \mathrm{~m}$, the snow temperatures in January 2007 were the same as those in January 2008. Taking into account the effect of density on heat conductivity (Sturm and Johnson, 1992; 

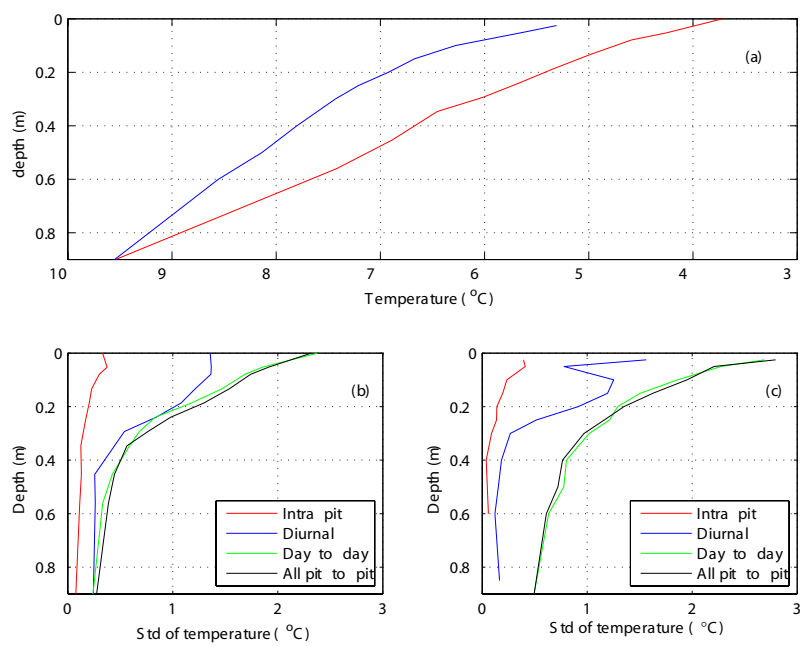

Fig. 3. Small-scale snow temperature observations near Basen nunatak: vertical profiles of (a) mean snow temperature in summers 2006-2007 (red) and 2007-2008 (blue), (b) standard deviation of snow temperature at different scales in summer 2006-2007, and (c) summer 2007-2008.

see below for the density differences), we can estimate that in January 2007 the downward heat flux in the uppermost $0.90 \mathrm{~m}$ of the snow pack was roughly twice as large as in January 2008.

The intra-pit variability in snow temperature on the spatial scale of $0.4 \mathrm{~m}$ was compared against data from the 10-20-mlong horizontal profiles of snow temperatures with $1 \mathrm{~m}$ intervals. The latter data were analysed so that the std of snow temperature was calculated on the spatial scales of $2 \mathrm{~m}, 5 \mathrm{~m}$, and for the length of the entire profile. The std increased with increasing horizontal scale. For the entire profile length, the std was $0.6,0.5$, and $0.4^{\circ} \mathrm{C}$ at the depths of $0.025,0.10$, and $0.20 \mathrm{~m}$, respectively. These numbers are 50-190\% larger than the intra-pit std shown in Fig. 3c.

The profile shape in the uppermost $0.30 \mathrm{~m}$ clearly depended on the cloud conditions (Fig. 4), which strongly controlled the downward radiative fluxes. During both evenings and mornings, the mean snow temperatures in cloudy-sky conditions exceeded the mean snow temperatures in clearsky conditions at all depths. Due to the strong surface radiative cooling during clear nights (the net radiation was typically -50 to $-80 \mathrm{~W} \mathrm{~m}^{-2}$ ), the minimum temperatures at the depths of $0.05-0.3 \mathrm{~m}$ were observed during clear mornings (Fig. 4a). In the uppermost $0.10 \mathrm{~m}$, the morning mean clear-sky profile was warmer than at deeper layers because of the already increased penetration and absorption of shortwave radiation at the time of the measurements (before 11:00 UTC). The downward longwave radiation from clouds reduces the surface cooling during cloudy nights (net radiation -10 to $-20 \mathrm{~W} \mathrm{~m}^{-2}$ ), thus in cloudy mornings the snow temperatures were up to $2.4^{\circ} \mathrm{C}$ higher than in clear mornings.
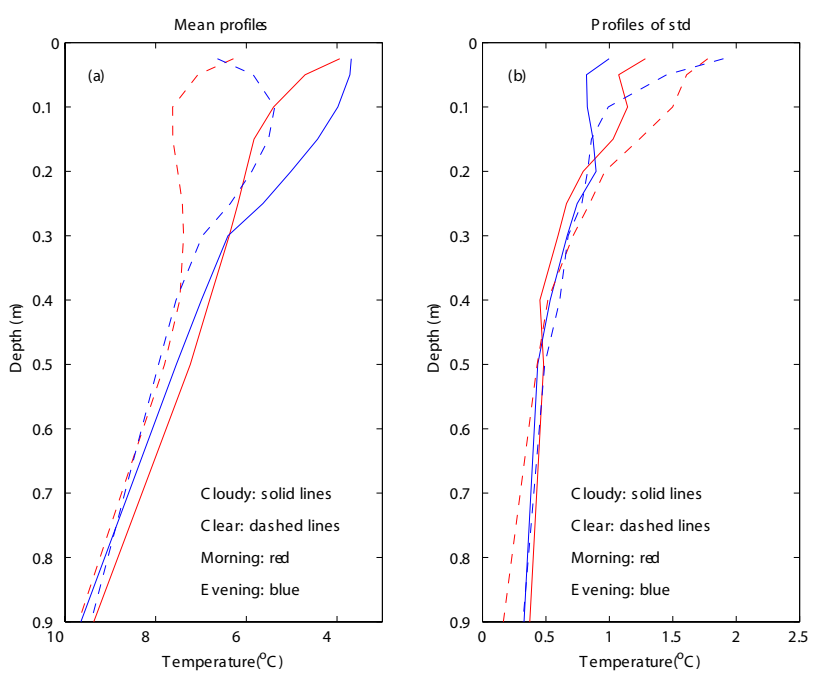

Fig. 4. Mean profiles of (a) snow temperature and (b) day-today standard deviation of snow temperature near Basen nunatak, averaged over the two summers but calculated separately for cloudy mornings (13 days), clear mornings (15 days), cloudy evenings (12 days), and clear evenings (15 days).

The maximum temperature difference between morning and evening was observed at the depth of $0.10 \mathrm{~m}$. It was larger under clear skies than cloudy skies (Fig. 4a), due to the larger diurnal cycle of net radiation under clear skies $\left(51 \mathrm{~W} \mathrm{~m}^{-2}\right)$ than cloudy skies $\left(31 \mathrm{~W} \mathrm{~m}^{-2}\right)$. At most measurement levels, the std was larger during clear-sky than cloudy conditions (difference up to $0.9^{\circ} \mathrm{C}$ ) and larger during mornings than evenings (difference up to $0.5^{\circ} \mathrm{C}$ ), except very close to the surface (See Sect. 5.3).

The snow temperatures were compared against the history of air temperature observed next to the snow pit site. The results are presented for summer 2006-2007, when the sample size was larger. The correlation coefficient was calculated between the snow temperature and air temperature history over a time range from $3 \mathrm{~h}$ to 10 days. In the uppermost $0.2 \mathrm{~m}$ the most important time scale was from 6 to $12 \mathrm{~h}$, with the highest $r$ exceeding 0.8 (Fig. 5). At deeper layers, not affected by the diurnal cycle, $r$ was lower and the most important time scale was $72 \mathrm{~h}$, with $\mathrm{r}$ ranging from 0.55 to 0.64 (removing the effects of autocorrelation, $r>0.41$ is significant with $95 \%$ confidence level).

\subsubsection{Snow density}

The snow density profiles (Fig. 6) showed large differences between the two summers. In 2006-2007 the snow density was higher than in 2007-2008 in the whole $0.5 \mathrm{~m}$ layer, with the maximum difference of $119 \mathrm{~kg} \mathrm{~m}^{-3}$ (40\%) observed at the surface. In 2006-2007 the minimum snow density was $390 \mathrm{~kg} \mathrm{~m}^{-3}$ at the depth of $0.10 \mathrm{~m}$ and the maximum was $445 \mathrm{~kg} \mathrm{~m}^{-3}$ at the depth of $0.50 \mathrm{~m}$, while in 2007-2008 the 


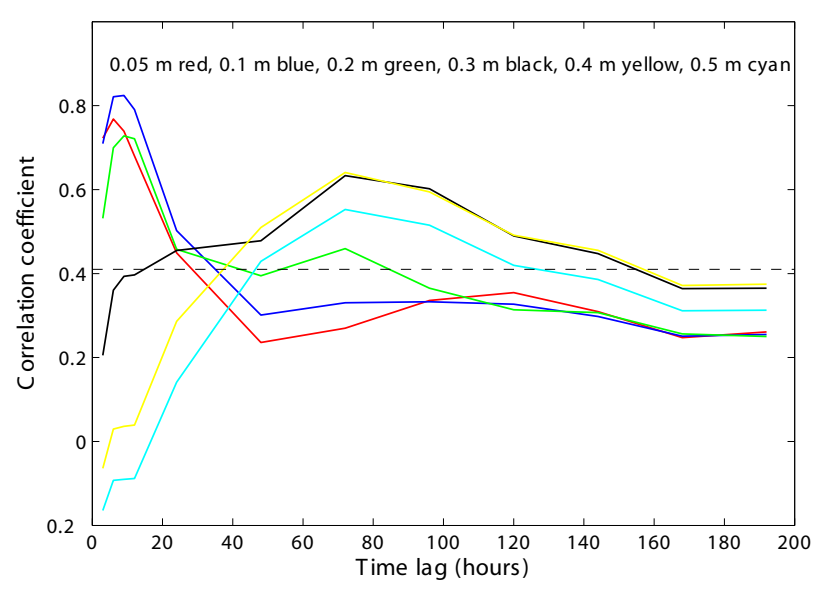

Fig. 5. The correlation coefficient between the air temperature history and the snow temperature in the uppermost $90 \mathrm{~cm}$ layer close to Basen nunatak in summer 2006-2007. The dashed line marks the threshold for $95 \%$ confidence level.
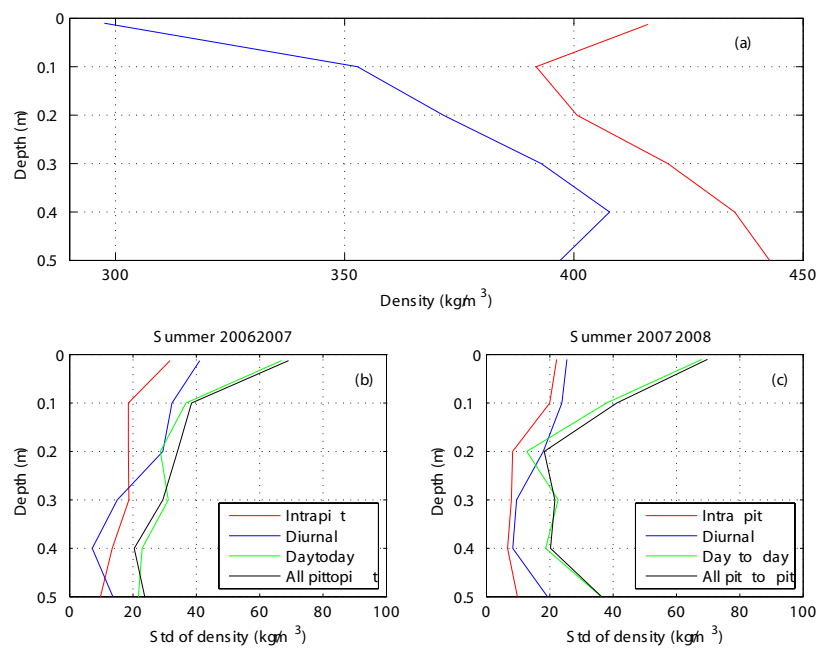

Fig. 6. Small-scale snow density observations near Basen nunatak: vertical profiles of (a) mean snow density in summers 20062007 (red) and 2007-2008 (blue), (b) standard deviation of snow density at different scales in summer 2006-2007, and (c) summer 2007-2008.

density decreased monotonically from the depth of $0.40 \mathrm{~m}$ towards the surface value of $300 \mathrm{~kg} \mathrm{~m}^{-3}$. The std of snow density had, however, rather similar profiles (Fig. $6 \mathrm{~b}$ and c). The std was largest in the uppermost $0.10 \mathrm{~m}$. The day-to-day variability dominated, and the diurnal cycle was generally larger than the intra-pit variability. The apparent diurnal cycle included, however, a contribution from the horizontal variability between the pits which were $1-10 \mathrm{~m}$ apart. The density measurements along the $10-20 \mathrm{~m}$ long lines suggested that it was probably responsible for most of the std (see below). According to the ECMWF operational analyses, the amount
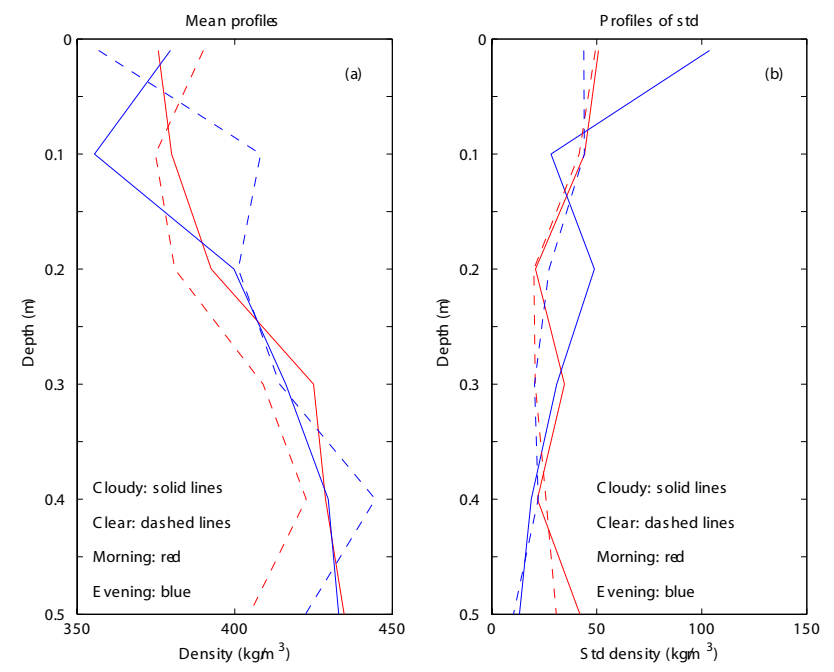

Fig. 7. Mean profiles of (a) snow density and (b) day-to-day standard deviation of snow density near Basen nunatak, averaged over the two summers but calculated separately for cloudy mornings (10 days), clear mornings (12 days), cloudy evenings (6 days), and clear evenings ( 9 days).

of snow fall in the Basen region in December-January 20072008 was 2.3 times that during the same period in the previous summer. The large accumulation of new snow has probably been the main reason for the lower density in summer 2007-2008.

The horizontal profile measurements along the $10-20 \mathrm{~m}$ long lines demonstrated that the std increased with horizontal scale (calculated for $2 \mathrm{~m}, 5 \mathrm{~m}$, and the entire profile length), and at all scales reached its maximum at the depth of $0.10 \mathrm{~m}$. For the entire profile length, the mean values at the depths of $0.01,0.10$, and $0.20 \mathrm{~m}$ were 36,48 , and $24 \mathrm{~kg} \mathrm{~m}^{-3}$, respectively. The numbers are $60-200 \%$ larger than the intra-pit std shown in Fig. 6c.

In the uppermost $0.10 \mathrm{~m}$, the snow density was dependent on the time of the day and the cloud conditions (Fig. 7). The near-surface $(0.01 \mathrm{~m})$ density was highest in clear mornings and lowest in clear evenings. These observations arise because during clear days the strongest melting and downward penetration of melt water reduced the near-surface density (Pirazzini et al., 2006) but increased the density via refreezing of the melt water at the depth of approximately $0.10 \mathrm{~m}$, seen in clear evenings in Fig. 7a. Melting was diagnosed on the basis of pyrgeometer-based surface temperature data and visual observations of the formation of ice layers. Further, the most efficient refreezing during clear nights increased the near-surface density, causing the largest values to be observed in clear mornings.

The snow density observations were compared against the history of air temperature, wind speed, downward solar radiation, and occurrence of snow fall. The only statistically significant relationship was that the density at the depth of $0.3 \mathrm{~m}$ 

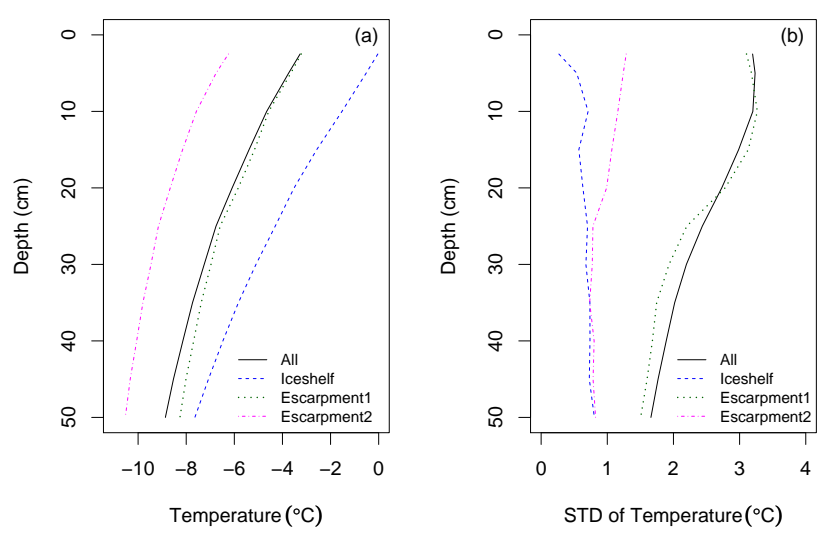

Fig. 8. Profiles of mean temperature (left) and horizontal standard deviation of temperature (right) from the $310 \mathrm{~km}$ transect (from the entire transect and from separate sections of the transect) during the season 2004/2005.

correlated with the mean solar radiation during the 10 days preceding the density observation $(r=0.60)$.

\subsection{Spatial and inter-annual variability along the transect}

Observations of the vertical profiles of the mean and std of snow temperature in summer 2004-2005 are presented in Fig. 8. The mean profiles clearly show the warmest snow on the ice shelf and coldest on Escarpment 2. Close to the surface, Escarpment 1 is $3.3^{\circ} \mathrm{C}$ and Escarpment 2 is $6.3^{\circ} \mathrm{C}$ colder than the ice shelf, but the differences decrease with depth. The mean altitudes are $63 \mathrm{~m}$ for the ice shelf, $469 \mathrm{~m}$ for Escarpment 1, and $1017 \mathrm{~m}$ Escarpment 2. Hence, with the dry-adiabatic lapse rate of $9.8^{\circ} \mathrm{C} \mathrm{km}^{-1}$, we calculate that the potential temperature is $0.7^{\circ} \mathrm{C}$ higher on Escarpment 1 than on the ice shelf, and $3.0^{\circ} \mathrm{C}$ higher on Escarpment 2 than on the ice shelf. See Sect. 5 for a discussion on the reasons for this.

Considering snow density, the $50 \mathrm{~km}$ subsection of the full $310 \mathrm{~km}$ transect was measured four times (17 and 23 December 2004, 2 and 14 January 2005). On each measurement day, 6 to 8 pits were measured along the subsection. The mean density varied between 360 and $440 \mathrm{~kg} \mathrm{~m}^{-3}$ (Fig. 9b). The horizontal std of density was calculated on the basis of time-averaged data from each pit. The std varied between 30 and $73 \mathrm{~kg} \mathrm{~m}^{-3}$ generally increasing with depth (Fig. 9d). A precipitation event was observed on 7 to 8 January 2005, yielding $0.02 \mathrm{~m}$ water equivalent of snow fall according to the ECMWF analyses. This probably generated noise in the std profiles, as the depths of different layers changed and new surface micro-topography was created. The spatial variability accounts for $50-87 \%$ of the total variability in snow density along the $50 \mathrm{~km}$ subsection.

Over the $310 \mathrm{~km}$ transect the density ranged from $150 \mathrm{~kg} \mathrm{~m}^{-3}$ (newly fallen snow) to $700 \mathrm{~kg} \mathrm{~m}^{-3}$ (a result of
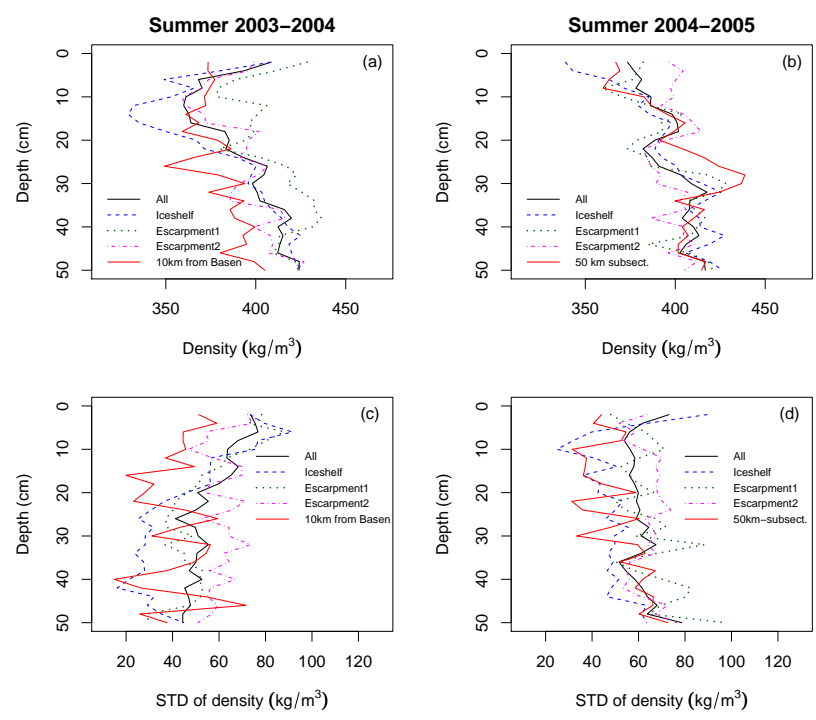

Fig. 9. Profiles of mean density (upper panels) and standard deviation of density (lower panels) from the $310 \mathrm{~km}$ transect (from the entire transect and from separate sections of the transect), from a site $10 \mathrm{~km}$ south of Basen, and from the $50 \mathrm{~km}$ subsection during seasons 2003/2004 (left) and 2004/2005 (right).

melting and refreezing) with a mean density of $380 \mathrm{~kg} \mathrm{~m}^{-3}$ and std of $70 \mathrm{~kg} \mathrm{~m}^{-3}$. On the ice shelf, in summer 20042005 , the mean density was lower close to the surface and higher at the depths of 0.1 to $0.2 \mathrm{~m}$ than in summer 20032004 (Fig. 9). On the basis of the ECMWF analyses, the summer 2-m air temperature over the ice shelf was higher in 2004-2005 than in 2003-2004 (Fig. 10), and therefore more melting probably occurred. The penetration of melt water would decrease the density at the top of the snow cover and increase it $0.10-0.30 \mathrm{~m}$ below the surface. According to the ECMWF analyses, the uppermost $0.20 \mathrm{~m}$ of snow at the time of the field campaigns had accumulated mainly in autumn and winter in 2004, while mostly in late winter, spring, and early summer in 2003 . The snow that accumulated later in the season in 2003 was subjected to a shorter period of compression and erosion by the wind before the summer measurement campaign compared to in December 2004, and therefore it remained less dense in the layer between the depths of 0.05 and $0.20 \mathrm{~m}$. The wind speed from the ECMWF analyses did not show differences between the two years along the transect. The std of density was 5-15\% larger in 2004-2005 than in 2003-2004 (Fig. 9c and d). This was probably due to the higher air temperature in summer 2004-2005 and earlier snow accumulation in 2004.

The subjective hardness measurements revealed features similar to those in density (Fig. 11). Over the ice shelf the snow layer was more horizontally homogeneous and had a better defined vertical structure than in the escarpment region (compare also with Fig. 9c and d). The cumulative precipitation, based on ECMWF analyses, during the whole year 

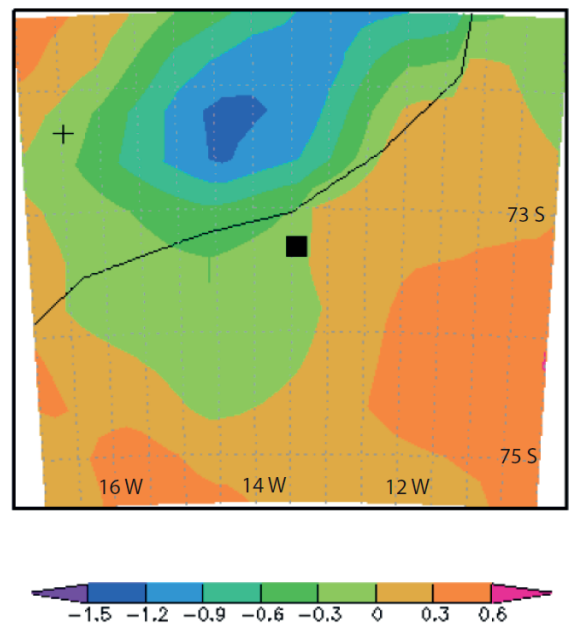

Fig. 10. Difference in 2-m air temperature (in ${ }^{\circ} \mathrm{C}$ ), based on the ECMWF operational analyses, between the two measurement campaigns (2003/2004-2004/2005) during the Rampen-Basen transect. Basen is marked by the square and Rampen by the cross.

before and during the measurement campaigns showed an accumulation maxima over the ice-shelf and a minima on Escarpment 2 (Fig. 12). The higher precipitation near the coast reduced the vertical and horizontal heterogeneity, which was more pronounced in layers that had been exposed longer to wind erosion and surface melting/sublimation. The correlation coefficient between density and hardness in the top $0.50 \mathrm{~m}$ was 0.55 in 2003-2004 and 0.43 in 2004-2005 with $p<0.01$ in both cases (Fig. 13). The co-variation of density and layering is also visible in Fig. 11 where the density isolines correspond well to the hardness features in the layering.

In 2003-2004, the section of the transect between sites 1142 and 1152 was the last to be measured, about one week after the other sections. The area had therefore developed a more complex layering, with some thick layers of ice due to the re-freezing of penetrated melt water which resulted from an intense melting period which occurred before the last section was measured. The snow hardness displayed a very different structure in the layering of this section compared to the neighbouring regions (Fig. 11, upper panel), with softening in the top $0.10 \mathrm{~m}$ due to surface melting and hardening at greater depths due to re-freezing.

\section{Discussion}

\subsection{Spatial variability in snow density}

Our measurements on the spatial variability of snow density covered scales ranging from $0.4 \mathrm{~m}$ to $100 \mathrm{~km}$ (with some analyses also for the whole 310-km transect). In Fig. 14 we summarize the results including for comparison the results of Sturm and Benson (2004) on the scale of $280 \mathrm{~m}$. The main message is the general increase of the std with increasing spatial scale. In this respect, the results of Sturm and Benson (2004) fit very well between our results for smaller and larger scales (except at the depth of $0.02 \mathrm{~m}$ ). Sturm and Benson (2004) stressed the importance of wind in generating the maximum heterogeneity in the snow pack structure at the $100 \mathrm{~m}$ scale, because this is the scale of many snow-drift features. Focusing on the vertically averaged values, we do not see any peaks in std at the scale of $100 \mathrm{~m}$. The conclusion of Sturm and Benson (2004) on the peak in heterogeneity at the scale of $100 \mathrm{~m}$ was, however, mostly based on results from the stratigraphic structure of the snow pack, instead of density data. We interpret the monotonous increase in the std to result from the fact that, when the scale increases, more processes generating heterogeneity start to be important and the processes already acting on smaller scales do not loose their importance. The most rapid increase in the spatial std of snow density takes place between the scales of 0.4 and $2 \mathrm{~m}$, which is most probably related to the typical size of sastrugi (Goodwin, 1990): measurements with $0.4 \mathrm{~m}$ intervals are more often taken from the same sastruga, or from the same flat area between sastrugi, than measurements with $2 \mathrm{~m}$ intervals.

Areas affected by strong katabatic winds create strong sastrugi formations during winter. In spring and summer precipitation due to synoptic-scale cyclones can level some of the rough surface creating less dense depositional layers and smoothing the surface, thus creating horizontal sub-surface density heterogeneity on the scale of $\sim 1 \mathrm{~m}$, which is characteristic of sastrugi (Goodwin, 1990). This is also apparent in the stratigraphic observations from our study region. Both 2003-2004 and 2004-2005 observations show thick snow layers with low hardness over the ice shelf and more variability between the sites 1160 and 1175 (Fig. 11).

An increase in density can usually be associated with an increase in the degree of bonding between the ice grains. Bonding of grains is also closely correlated with the penetration resistance of the snow, i.e. the hardness. The dependence between density and hardness is not straightforward, but depends on the metamorphism, which causes variation in their correlation (Dadic et al. 2008), also seen from Fig. 13. The recent snow fork observations of Sugiyama et al. (2010) along a transect between Aboa and Syowa stations suggested that weak bonding between snow grains due to depth-hoar formation occurs under extremely low temperatures. Our observations did not include clear indications of depth-hoar formation, which was probably due to the shallower measurement layer $(0.5 \mathrm{~m}$ instead of $1.0 \mathrm{~m}$ in Sugiyama et al., 2010) and the warmer climate in our measurement area.

The large-scale spatial variability of snow properties is strongly affected by the spatial variability in snow accumulation (Rotschky et al., 2007). Frezzotti et al. (2007) and Eisen et al. (2008) argue that in general the snow accumulation variability in East Antarctica on scales 0.1 to $100 \mathrm{~m}$ is controlled by wind-induced surface features, i.e. sastrugi and 

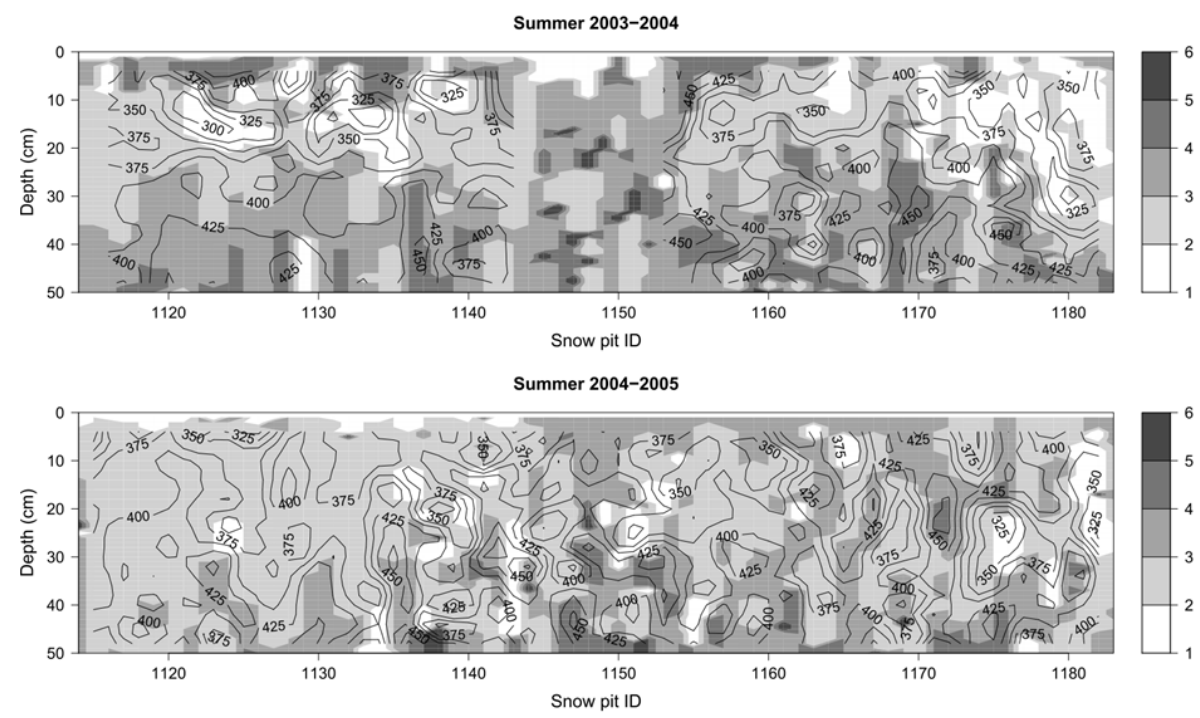

Fig. 11. Subjective layer hardness (grey scale, see Table 2) from the whole snow pit transect from 2003/2004 (top) and 2004/2005 (bottom). On the $\mathrm{x}$-axis are the ordinal numbers corresponding to the snow pit sites, located $5 \mathrm{~km}$ apart from each other (see Fig. 1). The contours indicate the snow density (in $\mathrm{kg} \mathrm{m}^{-3}$ ).

$1.2 .2003-31.1 .2004$

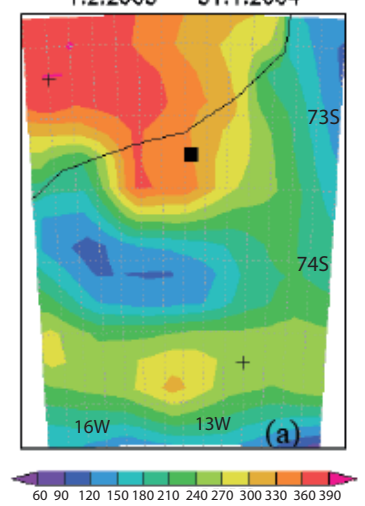

$1.2 .2004-31.1 .2005$

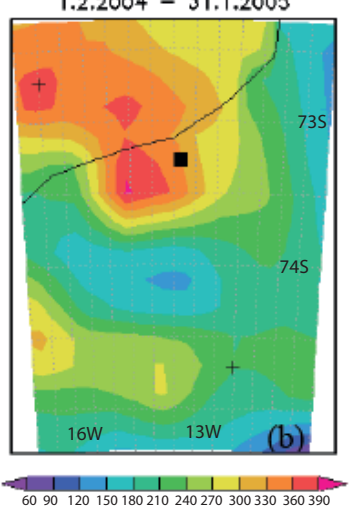

Fig. 12. Cumulative precipitation (in mm water equivalent) in the measurement area $\left(72-75^{\circ} \mathrm{S}, 343-350^{\circ} \mathrm{E}\right)$ according to ECMWF operational 24-h forecasts for (a) an annual period ending on 31 January 2004 (end of the measurement campaign) and (b) an annual period ending on 31 January 2005 (end of the measurement campaign). The upper cross, the square, and the lower cross mark the location of Rampen, Aboa, and Svea, respectively.

dunes. Scales from $10 \mathrm{~m}$ up to $10 \mathrm{~km}$ are governed by the interaction of topography and wind, whereas largest scales (from 100 to $4000 \mathrm{~km}$ ) are controlled by the synoptic climate. Our density data indicated a sharp increase in variability between the scales of 0.4 to $2 \mathrm{~m}$, a small increase up to the $300 \mathrm{~m}$ scale, and a stronger increase towards the $100 \mathrm{~km}$ scale, except at the surface (Fig. 14). The above suggests that variations in accumulation were the main driver of the horizontal variability in snow density.
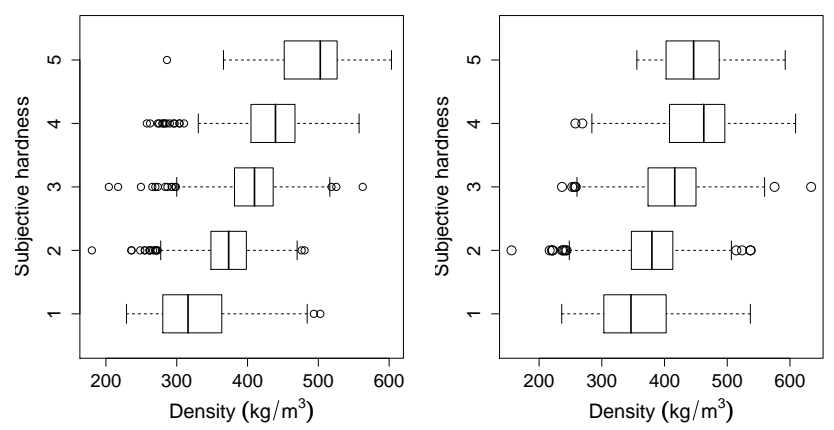

Fig. 13. Relationship between snow density and subjective hardness along the transect sampled during summer 2003/2004 (left) and 2004/2005 (right). See Table 2 for the hardness classes in the $y$-axis. The vertical line inside the box describes the median for the current class, the box extends from the $25 \%$ quartile to $75 \%$ quartile and the whiskers extend to 1.5 times the inter-quartile range. Outliers are shown as separate markers.

According to Van den Broeke et al. (1999), farther west in Dronning Maud Land (from 3 to $15^{\circ} \mathrm{E}$ ), the snow density of the uppermost $1 \mathrm{~m}$ generally decreased with increasing distance from the coast. The data of Kärkäs et al. (2005) and our data presented here did not show any significant correlation between the density and the distance from the coast. This is probably due to the fact that we only studied the uppermost $0.5 \mathrm{~m}$ of the snow pack, where individual precipitation and melting events had a large effect on the snow density. This results in density profiles with a lot of vertical variability without systematic differences between the ice shelf and Escarpments 1 and 2 (Fig. 9a and b). 


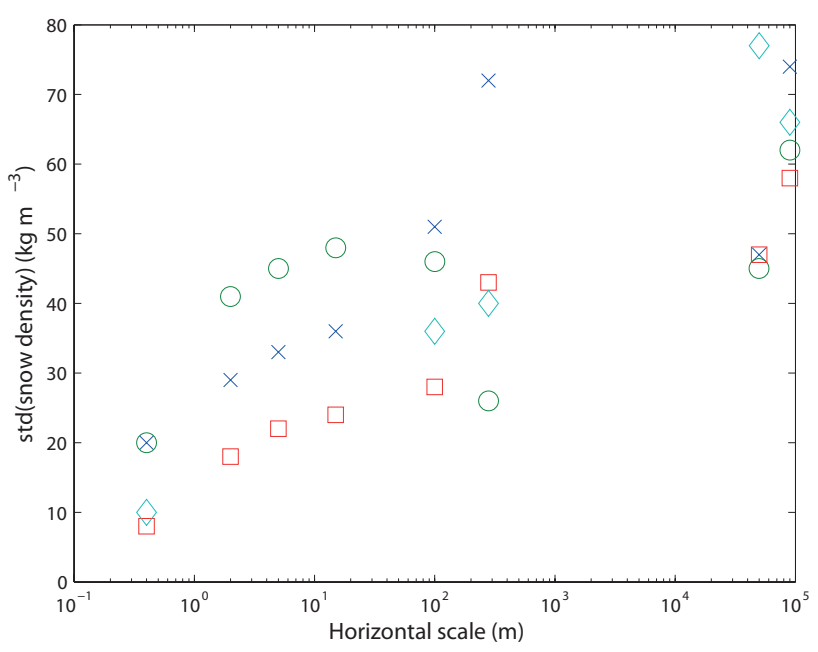

Fig. 14. Spatial standard deviation of snow density measured at various sampling scales. The results for the horizontal scale of $280 \mathrm{~m}$ are calculated on the basis of the data presented in Fig. 7 of Sturm and Benson (2004). The measurement depth is indicated by crosses for $0.02 \mathrm{~m}$, circles for $0.1 \mathrm{~m}$, squares for $0.2 \mathrm{~m}$, and diamonds for $0.5 \mathrm{~m}$.

\subsection{Spatial variability in snow temperature}

Similarly to Granberg et al. (2009), who studied the same region, we observed that the potential temperatures of the upper snow pack decreased from inland (about $300 \mathrm{~km}$ from the coast) towards the coast. An analogous gradient in potential temperature perpendicular to the coast was also observed in a nearby area in Dronning Maud Land by Van den Broeke et al. (1999). Granberg et al. (2009) suggested that strong sublimation of wind-blown snow associated with katabatic winds is an important factor in generating this gradient, but did not give any quantitative estimates of the sublimation. We note, however, that in the ECMWF analyses the annual mean surface potential temperature strongly decreases towards the ice shelf $\left(0.03^{\circ} \mathrm{C} \mathrm{km}^{-1}\right.$ in our study region $)$ although the model does not include any parameterization of sublimation from blowing/drifting snow, but just from the surface. Other arguments against the conclusion of Granberg et al. (2009) are that (a) the katabatic winds strongly attenuate over the almost flat ice shelves (Van den Broeke and van Lipzig, 2003; Renfrew, 2004) and (b) due to the vicinity of the sea and the larger cyclone activity, the air humidity over the ice shelves is higher than in the interior (Tietäväinen and Vihma, 2008). These factors reduce sublimation related to katabatic winds over ice shelves. We conclude, in agreement with Hogan (1997), Van den Broeke et al. (1999), and van den Broeke and van Lipzig (2003), that the commonly observed decrease in potential temperature from escarpments towards the ice shelves is caused by the accumulation of cold near-surface air brought by katabatic winds onto the ice shelves. In addition, when the katabatic winds attenuate over the ice shelves, the stratification increases resulting in further cooling of near-surface air. Further, the observed distribution of surface potential temperature is also favoured by the large-scale southward advection of warm air, which peaks well above sea level, balancing the near-surface katabatic outflow (King and Turner, 1997). Finally, model experiments of Lenaerts et al. (2010) suggested that even when sublimation from drifting snow is large, the effects on the snow surface temperature remain minor (Fig. 11 in Lenaerts et al., 2010). Analogously, we do not agree with Granberg et al. (2009) that higher potential temperatures at Högisen (Fig. 1) could be due to condensation heating in the katabatic layer as it ascends the hill.

\subsection{Temporal variability in snow density and temperature}

Although the day-to-day variability dominated the temporal variability in snow temperature and density, the results demonstrate that the diurnal cycle of snow temperature is clearly present in the study region during summer, when the sun did not set but its zenith angle varied from $50^{\circ}$ to $89^{\circ}$. The penetration depth $(0.20-0.25 \mathrm{~m})$ of the diurnal temperature cycle was close to that obtained by van Lipzig et al. (1999) at Svea in January 1993, by Jordan et al. (1989) for seasonal snow in New Hampshire, USA, in February, and by Cheng et al. (2008a, b) for snow on the Arctic sea ice in summer. In all of these studies, the diurnal range of the solar zenith angle was between $36^{\circ}$ and $43^{\circ}$. Although melting occurred at the measurement site close to Basen, it was so limited that it did not have detectable effects on the diurnal cycle. This was also the case for the diurnal cycle of snow surface temperature during the Ice Station Polarstern in the western Weddell Sea in December 2004 (Vihma et al., 2009).

The temperature profiles in the uppermost $0.30 \mathrm{~m}$ strongly depended on the cloud conditions, which controlled the downward radiative fluxes with opposite effects on solar shortwave and thermal longwave radiation. Around noon the net radiation was almost the same $\left(40 \mathrm{~W} \mathrm{~m}^{-2}\right)$ under clear and cloudy skies, but during clear nights the net radiation was typically -50 to $-80 \mathrm{~W} \mathrm{~m}^{-2}$ compared to -10 to $-20 \mathrm{~W} \mathrm{~m}^{-2}$ during cloudy nights. The reason for the observed larger day-to-day variability in the clear-sky temperature profiles compared to the cloudy profiles (Fig. 4b) can be explained as follows. While temperature maxima were close to the melting point in most of clear and cloudy days, temperature minima were much lower in clear days, due to the stronger nocturnal heat loss. Thus, the daily excursion of surface temperature was $8-12{ }^{\circ} \mathrm{C}$ larger in clear than cloudy days, and day-to-day differences in the exact timing of the temperature measurements between 18:00 and 22:00 UTC generated the larger std in clear compared to cloudy days.

Temporal variations in snow temperature in time scales of hours and days were well explained by the weather history, 
but temporal variations in snow density were not as well explained. This was probably due to the following. First, during the summer season in the vicinity of the open sea, the density of newly fallen snow varied a lot from event to event. Under warm weather, snow fall did not always result in a smaller density at the surface layer. Second, melting had different, even opposing effects on snow density at different depths.

Inter-annual variations in snow density were large, up to 40\%, between summers 2006-2007 and 2007-2008. The large accumulation of new snow, together with the colder weather and less snow metamorphosis were probably the main reasons for the lower density in summer 2007-2008. The large accumulation of new snow may also have contributed to the large day-to-day std in snow temperature in 2007-2008; new snow with low heat conductivity makes the near-surface snow temperatures more sensitive to synopticscale changes in the air temperature. The snow density variations between summers 2003-2004 and 2004-2005 were smaller, and their reasons were therefore less clear. The transect data revealed, however, that snow density and stratification were strongly affected by single precipitation events.

\subsection{Comparison of spatial and temporal variability}

On the intra-pit scale of $0.4 \mathrm{~m}$, the temporal variability in snow density (dominated by the day-to-day variability) was much larger than the horizontal variability throughout the uppermost $0.50 \mathrm{~m}$ layer (Fig. 6). Both the horizontal variability and the day-to-day variability in density decreased with depth, but the latter decreased more rapidly. Hence, the relative magnitude of the horizontal compared to the day-to-day variability increased with depth. Assuming that the temporal variability of snow density shown in Fig. $6 \mathrm{~b}$ and $\mathrm{c}$ is also representative for the environment of the large-scale transect measurements, it reached the magnitude of the large-scale horizontal variability (Fig. 9c and d) only in the uppermost centimetres, but the horizontal variability dominated by the depth of $0.10 \mathrm{~m}$.

Considering the std of snow temperature (Fig. 3b and c), the temporal variability, both on a day-to-day scale and due to the diurnal cycle, exceeded the horizontal variability on the intra-pit scale of $0.4 \mathrm{~m}$ throughout the $0.50 \mathrm{~m}$ layer. In the uppermost $0.40 \mathrm{~m}$, this was also the case when the total and day-to-day temporal variability was compared against the horizontal variability along the Ice Shelf and Escarpment 2 (Figs. 3 and 8, assuming that the Basen measurements also represent the temporal variability along the transect). In Escarpment 1, however, the large-scale horizontal variability dominated. At both small and large scales, the relative magnitude of the horizontal variability was largest in the lower part of the $0.50 \mathrm{~m}$ deep layer. This was due to the temporal variability increasing more strongly towards the surface.

\section{Conclusions}

We observed large inter-annual variations in the uppermost $0.5 \mathrm{~m}$ of the snow pack. In 2007-2008 the snow temperatures were as much as $1.4{ }^{\circ} \mathrm{C}$ lower than in the previous summer. In 2006-2007 the snow density was higher than in 2007-2008 in the whole $0.5 \mathrm{~m}$ layer, the maximum difference of $40 \%$ at the surface. These differences were due to inter-annual differences in air temperature and precipitation, and in the timing of the precipitation events.

Considering time scales of hours and days, the temperature of the uppermost $0.2 \mathrm{~m}$ of the snow pack was strongly correlated with the mean air temperature during the preceding 6 to $12 \mathrm{~h}(r>0.8)$. At deeper layers, not affected by the diurnal cycle, $r$ was lower and the most important time scale was $72 \mathrm{~h}$. Short-term temporal variations of snow density were less well explained, but the history of solar radiation on a time scale of 10 days controlled the density at the depth of $0.3 \mathrm{~m}$. Even though the measurements were taken in summer time, the cloud radiative forcing was positive in the study region. Temperature maxima were close to the melting point during most clear and cloudy days, but temperature minima were much lower during clear days than during cloudy days. The effects of cloud cover on snow temperature (density) were clearly detected in the uppermost $0.3 \mathrm{~m}$ $(0.1 \mathrm{~m})$.

Both in the intra-pit and transect scales, the ratio of the horizontal to temporal variability increased with depth. On the intra-pit scale the temporal variability in snow density exceeded the horizontal variability throughout the uppermost $0.5 \mathrm{~m}$ layer, but on the $100-\mathrm{km}$ scale the horizontal variability dominated beneath the depth of $0.1 \mathrm{~m}$. For the snow temperature close to Basen, day-to-day variability dominated ( $\operatorname{std}>2{ }^{\circ} \mathrm{C}$ in the uppermost centimetres), while the diurnal cycle was of next importance $\left(\operatorname{std}>1{ }^{\circ} \mathrm{C}\right)$ and horizontal variability on the scale of 0.4 to $10 \mathrm{~m}$ was least significant $\left(\right.$ std $\left.\leq 0.6^{\circ} \mathrm{C}\right)$. Day-to-day temporal variability also exceeded the horizontal variability along the ice shelf and Escarpment 2. In Escarpment 1, however, the large-scale horizontal variability dominated. The main difference between the variability of snow density and temperature was that the relative importance of the horizontal compared to the temporal variability was larger for density. This we interpreted to be a consequence of (a) the role of heat conduction which smoothes horizontal variations in temperature more effectively than those in density and (b) variability in the radiative and turbulent surface fluxes that generates temporal variations in temperature more directly than in density.

The horizontal std of snow density and temperature increased with spatial scale. The most rapid increase took place between the scales of 0.4 and $2 \mathrm{~m}$, which is most probably related to the typical size of sastrugi. Considering future field work, our results suggest that observations on a scale of $10 \mathrm{~m}$ can reasonably well represent the scale of $100 \mathrm{~m}$, if there are no major topographic features. On 
the other hand, to better understand the spatial variability, more density observations are needed on spatial scales of 0.4 to $10 \mathrm{~m}$ and 1 to $10 \mathrm{~km}$. Nested sampling at these scales is potentially a cost-effective approach. Further, in lowaccumulation sites, relatively small differences in accumulation rates $\left(<0.040 \mathrm{~m}\right.$ w.e. $\left.\mathrm{yr}^{-1}\right)$ cause differences in the residence time of the snow crystals in the near-surface layer, which may result in large differences in the snow's physical properties, such as grain size and thermal conductivity, without significant differences in density (Courville et al., 2007). Hence, in future field experiments which investigate the surface energy balance, the grain size and thermal conductivity should also be measured.

Our snow density data are of interest for the problem of converting snow stake and satellite altimeter data to surface mass balance. In particular, the results for the spatial variability of density are valuable in estimating error margins for regional surface mass balance (Wingham, 2000). Together with accurate information on accumulation, e.g. from ice cores (Rotschky et al., 2007), high-resolution snow density and temperature data can also be applied to validate firn densification models. For this purpose, future field work should also include measurements from deeper layers ( $\mathrm{Li}$ et al., 2002). This is supported by Takahashi and Kameda (2007), who suggested that snow density at the base of the snow stake should be used to estimate water equivalent surface mass balance from stake measurements. Our data set also provides possibilities for the validation of snow thermodynamic models from the point of view of the dependence of thermal conductivity on density (Brandt and Warren, 1997) and penetration of solar radiation into the snow pack (Cheng et al., 2008a).

Acknowledgements. The study was supported by the Academy of Finland (contracts 128533 and 127691). We thank Eija Kanto for help in obtaining the field measurements. We are grateful to two anonymous reviewers for comments on the manuscript and to Victoria Sinclair for correcting the English. FINNARP is acknowledged for logistics support, and ECMWF for providing the operational model data.

Edited by: S. Marshall

\section{References}

Brandt, R. E. and Warren, S. G.: Temperature measurements and heat transfer in near-surface snow at the South Pole, J. Glaciol., 43, 339-351, 1997.

Bromwich, D. H. and Fogt, R. L.: Strong trends in the skill of the ERA-40 and NCEP/NCAR Reanalyses in the high and middle latitudes of the Southern Hemisphere, 1958-2001, J. Climate, 17, 4603-4619, 2004.

Bromwich, D. H., Fogt, R. L., Hodges, K. E., and Walsh, J. E.: A tropospheric assessment of the ERA-40, NCEP, and JRA-25 global reanalyses in the polar regions, J. Geophys. Res., 112, D10111, doi:10.1029/2006JD007859, 2007.

Cheng, B., Zhang, Z., Vihma, T., Johansson, M., Bian, L., Li, Z., and $\mathrm{Wu}, \mathrm{H}$.: Model experiments on snow and ice thermodynamics in the Arctic Ocean with CHINARE2003 data, J. Geophys. Res., 113, C09020, doi:10.1029/2007JC004654, 2008a.

Cheng, B., Vihma, T., Zhang, Z., Li, Z., and Wu, H.: Snow and sea ice thermodynamics in the Arctic: Model validation and sensitivity study against SHEBA data, Chinese J. Polar Sci., 19, 108122, 2008b.

Colbeck, S.: Layered character of snow covers, Rev. Geophys., 29, 81-96, 1991.

Colbeck, S. C., Akitaya, E., Armstrong, R., Gubler, H., Lafeuille, J., Lied, K., McClung, D., and Morris, E.: International classification for seasonal snow on the ground, International Commision on Snow and Ice of the International Association of Scientific Hydrology, World Data Centre - Association for Glaciology, Univeristy of Colorado, Boulder, CO, 23 pp., 1990.

Courville, Z. R., Albert, M. R., Fahnestock, M. A., Cathles IV, L. M., and Shuman, C. A.: Impacts of an accumulation hiatus on the physical properties of firn at a low-accumulation polar site, J. Geophys. Res., 112, F02030, doi:10.1029/2005JF000429, 2007.

Dadic, R., Schneebeli, M., Lehning, M., Hutterli, M. A., and Ohmura, A.: Impact of the microstructure of snow on its temperature: A model validation with measurements from Summit, Greenland, J. Geophys. Res., 113, D14303, doi:10.1029/2007JD009562, 2008.

Dell'Aquila, A., Ruti, P. M., Calmanti, S., and Lucarini, V.: Southern Hemisphere midlatitude atmospheric variability of the NCEP-NCAR and ECMWF reanalyses, J. Geophys. Res., 112, D08106, doi:10.1029/2006JD007376, 2007.

Eisen, O., Frezzotti, M., Genthon, C., Isaksson, E., Magand, O., van den Broeke, M. R., Dixon, D. A., Ekaykin, A., Holmlund, P., Kameda, T., Karlöf, L., Kaspari, S., Lipenkov, V. Y., Oerter, H., Takahashi, S., and Vaughan, D. G.: Ground-based measurements of spatial and temporal variability of snow accumulation in East Antarctica, Rev. Geophys., 46, RG2001, doi:10.1029/2006RG000218, 2008.

Frezzotti, M., Gandolfi, S., La Marca, F., and Urbini, S.: Snow dunes and glazed surfaces in Antarctica: new field and remotesensing data, Ann. Glaciol., 34, 81-88, 2002a.

Frezzotti, M., Gandolfi, S., and Urbini, S.: Snow megadunes in Antarcitca: sedimentary structure and genesis, J. Geophys Res., 107, 4344, doi:10.1029/2001JD000673, 2002b.

Frezzotti, M., Pourchet, M., Flora, O., Gandolfi, S., Gay, M., Urbini, S., Vincent, C., Becagli, S., Gragnani, R., Proposito, M., Severi, M., Traversi, R., Udisti, R., and Fily, M.: New estimations of precipitation and surface sublimation in East Antarctica from snow accumulation measurements, Clim. Dyn., 23, 803- 
813, doi:10.1007/s00382-004-0462-5, 2004.

Frezzotti, M., Urbini, S., Proposito, M., Scarchilli, C., and Gandolfi, S.: Spatial and temporal variability of surface mass balance near Talos Dome, East Antarctica, J. Geophys. Res., 112, F02032, doi:10.1029/2006JF000638, 2007.

Frey, M. M., Hutterli, M. A., Chen, G., Sjostedt, S. J., Burkhart, J. F., Friel, D. K., and Bales, R. C.: Contrasting atmospheric boundary layer chemistry of methylhydroperoxide $\left(\mathrm{CH}_{3} \mathrm{OOH}\right)$ and hydrogen peroxide $\left(\mathrm{H}_{2} \mathrm{O}_{2}\right)$ above polar snow, Atmos. Chem. Phys., 9, 3261-3276, doi:10.5194/acp-9-3261-2009, 2009.

Goodwin, I. D.: Snow accumulation and surface topography in the katabatic zone of Eastern Wilkes Land, Antarctica, Antarctic. Sci., 2, 235-242, 1990.

Granberg, H., Cliche, P., Mattila, O.-P., Kanto, E., and Leppäranta, M.: A snow sensor experiment in Dronning Maud Land, Antarctica, J. Glaciol., 55, 1041-1051, 2009.

Harper, J. T. and Bradford, J. H.: Snow stratigraphy over a uniform depositional surface: spatial variability and measurement tools, Cold Reg. Sci. Technol., 37, 289-298, 2003.

Helsen, M. M., van den Broeke, M. R., van de Wal, R. S. W., van de Berg, W. J., van Meijgaard, E., Davis, C. H., Li, Y., and Goodwin, I.: Elevation changes in Antarctica mainly determined by accumulation variability, Science, 320, 1626-1629, 2008.

Hogan, A.: A synthesis of warm air advection to the South Polar Plateau, J. Geophys. Res., 102, 14009-14020, 1997.

Jordan, R. E., O’Brian, H., and Albert, M. R.: Snow as a thermal background: preliminary results from the 1987 field test, in: Proc., Snow Symposium VII, US Army Cold Regions Research and Engineering Laboratory, Hanover, NH, Special Report 89-7, 5-24, 1989.

Kärkäs, E., Granberg, H., Kanto, K., Rasmus, K., Lavoie, C., and Leppäranta, M.: Physical properties of the seasonal snow cover in Dronning Maud Land, East Antarctica, Ann. Glaciol., 34, 8994, 2002.

Kärkäs, E., Martma, T. and Sonninen, E.: Physical properties and stratigraphy of surface snow in western Dronning Maud Land, Antarctica, Polar Research, 24, 55-67, 2005.

King, J. C. and Turner, J.: Antarctic Meteorology and Climatology, University Press Cambridge, Cambridge, 409 pp., 1997.

Kronholm, K., Schneebeli, M., and Schweizer, J.: Spatial variability of micropenetration resistance in snow layers on a small slope, Ann. Glaciol., 38, 202-208, 2004.

Lenaerts, J. T. M., van den Broeke, M. R., Dry, S. J., Knig-Langlo, G., Ettema, J., and Munneke, P. K.: Modelling snowdrift sublimation on an Antarctic ice shelf, The Cryosphere, 4, 179-190, doi:10.5194/tc-4-179-2010, 2010.

Li, J. and Zwally, H. J.: Modeling the density variation in the shallow firn layer, Ann. Glaciol., 38, 309-313, 2004.

Li, J., Wang, W., and Zwally, H. J.: Interannual variations of shallow firn temperature at Greenland summit, Ann. Glaciol., 35, 368-370, 2002.

Monaghan, A. J., Bromwich, D. H., Fogt, R. L., Wang, S.-H., Mayewski, P. A., Dixon, D. A., Ekaykin, A. A., Frezzotti, M., Goodwin, I. D., Isaksson, E., Kaspari, S. D., Morgan, V. I., Oerter, H., van Ommen, T. D., van der Veen, C. J., and Wen, J.: Insignificant change in Antarctic snowfall since the International Geophysical Year, Science, 313, 827-831, 2006.

McConnell, J. R., Arthern, R. J., Mosley-Thompson, E., Davis, C. H., Bales, R. C., Thomas, R., Burkhart, J. F., and Kyne, J. D.:
Changes in Greenland ice sheet elevation attributed primarily to snow accumulation variability, Nature, 406, 877-879, 2000.

Nicolaus, M., Haas, C., and Willmes, S.: Evolution of first-year and second-year snow properties on sea ice in the Weddell Sea during spring-summer transition, J. Geophys. Res., 114, D17109, doi:10.1029/2008JD011227, 2009.

Pirazzini, R.: Surface albedo measurements over Antarctic sites in summer, J. Geophys. Res., 109, D20118, doi:10.1029/2004JD004617, 2004.

Pirazzini, R., Vihma, T., Granskog, M. A., and Cheng, B.: Surface albedo measurements over sea ice in the Baltic Sea during the spring snowmelt period, Ann. Glaciol., 44, 7-14, 2006.

Reijmer, C. H. and Oerlemans, J.: Temporal and spatial variability of the surface energy balance in Dronning Maud Land, East Antarctica, J. Geophys. Res., 107(D24), 4759, doi:10.1029/2000JD000110, 2002.

Reijmer C. H., van den Broeke, M. R., and Scheele, M. P.: Air parcel trajectories and snowfall related in five deep drilling locations in Antarctica based on the ERA-15 dataset, J. Clim., 15, 1957-1968, 2002.

Reijmer, C. H. and van den Broeke, M. R.: Temporal and spatial variability of the surface mass balance in Dronning Maud Land, Antarctica, as derived from automatic weather stations, J. Glaciol., 49, 512-520, 2003.

Renfrew, I. A.: The dynamics of idealized katabatic flow over a moderate slope and ice shelf, Q. J. Roy. Meteorol. Soc., 130, 1023-1045, 2004.

Richardson, C., Aarholt, E., Hamran, S. E., Holmlund, P., and Isaksson, E.: Spatial distribution of snow in western Dronning Maud Land, East Antarctica, mapped by a ground-based snow radar, J. Geophys. Res., 102, 20343-20353, 1997.

Richardson-Näslund, C.: Spatial characteristics of snow accumulation in Dronning Maud Land, Antarctica, Glob. Planet. Change, 42, 31-43, 2004.

Rotschky, G., Holmlund, P., Isaksson, E., Mulvaney, R., Oerter, H., Van den Broeke, M. R., and Winther, J.-G.: A new surface accumulation map for western Dronning Maud Land, Antarctica, from interpretation of point measurements, J. Glaciol, 53, 385398, 2007.

Sihvola, A. and Tiuri, M.: Snow fork for field determination of density and wetness profiles of a snow pack, Trans. Geosc. Remote Sens., 24, 717-721, 1986.

Sturm, M. and Benson, C.: Scales of spatial heterogeneity for perennial and seasonal snow layers, Ann. Glaciol., 38, 253-260, 2004.

Sturm, M. and Johnson, J. B.: Thermal conductivity measurements on depth hoar, J. Geophys. Res., 97, 2129-2139, 1992.

Sugiyama, S., Enomoto, H., Fujita, S., Fukui, K., Nakazawa, F., and Holmlund, P.: Dielectric permittivity of snow measured along the route traversed in the Japanese-Swedish Antarctic Expedition 2007/08, Ann. Glaciol., 51, 9-15, 2010.

Takahashi, S. and Kameda, T.: Instuments and methods snow density for measuring surface mass balance using the stake method, J. Glaciol., 53, 677-680, 2007.

Tastula, E.-M. and Vihma. T.: WRF model experiments on the Antarctic atmosphere in winter, Mon. Weather Rev., in press, 2011.

Tietäväinen, H. and Vihma. T.: Atmospheric moisture budget over Antarctica and Southern Ocean on the basis of ERA-40 reanaly- 
sis, Int. J. Climatol., 28, 1977-1995, doi:10.1002/joc.1684, 2008.

Town, M. S., Waddington, E. D., Walden, V. P., and Warren, S. G.: Temperatures, heating rates and vapour pressures in near-surface snow at the South Pole, J. Glaciol., 54, 487-498, 2008.

Van den Broeke, M., C. and Van Lipzig, N. P. M.: Factors Controlling the Near-Surface Wind Field in Antarctica, Mon. Weather Rev., 131, 733-743, 2003.

Van den Broeke, M., Winther, J.-G., Isaksson, E., Pinglot, J. F., Karlöf, L., Eiken, T., Conrads, L.: Climate variables along a traverse line in Dronning Maud Land, East Antarctica, J. Glaciol., 45, 295-302, 1999.

Van den Broeke, M., Reijmer, C., van de Wal, R.: Surface radiation balance in Antarctica as measured with automatic weather stations, J. Geophys. Res., 109, D09103, doi:10.1029/2003JD004394, 2004.

Van Lipzig, N. P. M., van Meijgaard, E., and Oerlemans, J.: Evaluation of a regional atmospheric model using measurements of surface heat exchange processes from a site in Antarctica, Mon. Weather Rev., 127, 1994-2011, 1999.
Vihma, T., Uotila, J., Cheng, B., and Launiainen, J.: Surface heat budget over the Weddell Sea: buoy results and comparisons with large-scale models, J. Geophys. Res., 107(C2), 3013, doi:10.1029/2000JC000372, 2002.

Vihma, T., Johansson, M. M., and Launiainen, J.: Radiative and turbulent surface heat fluxes over sea ice in the western Weddell Sea in early summer, J. Geophys. Res., 114, C04019, doi:10.1029/2008JC004995, 2009.

Wingham, D. J.: Small fluctuations in the density and thickness of a dry firn column, J. Glaciol., 46, 399-411, 2000.

Zwally, H. J. and Li, J.: Seasonal and interannual variations of firn densification and ice-sheet surface elevation at Greenland summit, J. Glaciol., 48(161), 199-207, 2002. 